\title{
REGINA'S MUTE SWAN MYSTERY
}

\section{STUART HOUSTON, 863 University Drive, Saskatoon, Sask S7N 0J8}

We know when Mute Swans were first introduced to the brand new Regina Waterfowl Park in Regina: 1956, when swans first wintered on open water heated by the Power Plant. During the next 20 winters, the Regina Christmas Bird Count $(\mathrm{CBC})$ recorded one to twelve each winter, the final two on 26 December 1975. authority. The swans did not "wander" from New York nor was Godfrey his source. Christopher Lever's 1966 presumed arrival date is ten years late, and he too is wrong when he suggests that they "presumably dispersed [to Regina] from northwestern Michigan."3 Lever gave W.T. Munro, formerly of the CWS at Saint-Foie, Quebec, as

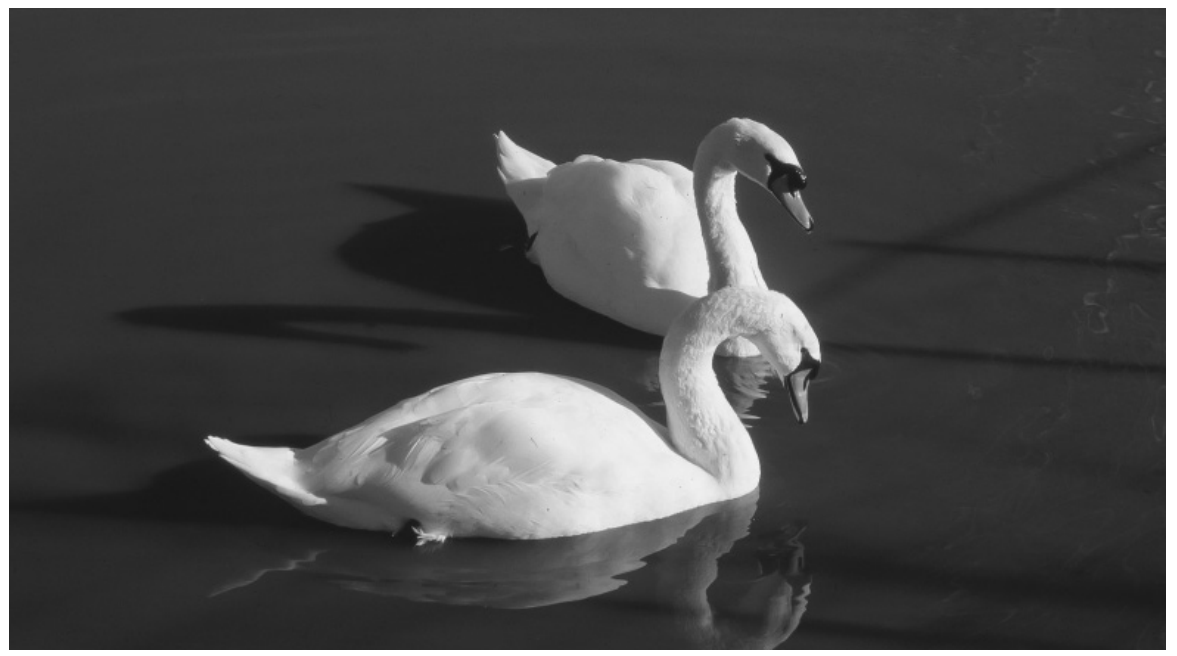

We know why the swans disappeared. Year-round presence of these stately birds was doomed when the power plant shut down for the first time in 1978-79 and the marsh froze. For an estimated three winters the swans were housed in pens as a temporary but unsustainable experiment. ${ }^{1}$

While we didn't then know where the swans came from, we could conclusively contradict erroneous statements in two otherwise reputable books. John L. Long's 1981 statement, "Recently reported to be nesting and wintering in Regina, Saskatchewan,"2 is true, but he concludes "probably after wandering from the New York region" 2 and gives Godfrey $1966^{4}$ as his his source, but Munro (pers. comm.) assures me he said no such thing.

Margaret Belcher in Birds of Regina ${ }^{5}$ wrote: "The Mute Swan is the familiar captive swan of city parks, beloved of photographers ... In the winter of 1956-57 four Mute Swans wintered in the open waters of the Waterfowl Park, and since then there have been Mute Swans there each winter". ${ }^{5}$ In her second edition, she adds "Some of the progeny of the wing-clipped birds brought into Regina have been full-winged birds." 1 This of course was true, because the permit requirement to pinion each hatchling when seven days old was not always followed. But the Belcher statements beg the question: 
Where did the Regina swans come from? Ottawa? The United States? England? Fred Lahrman, diorama artist at the Saskatchewan Museum of Natural History, thought the swans came from England. He told Lorne Scott that when Governor-General Vincent Massey opened the Saskatchewan Museum of Natural History, 16 May 1955, he promised on behalf of the Queen that a pair of Mute Swans would be sent to the brand new Wascana Waterfowl Park.

The Protocol Office in Regina referred me to Lee-Ann Irvine, Collections Registrar at the Royal Saskatchewan Museum, who dug into the museum archives and produced Regina LeaderPost clippings that give possible credence to the Lahrman hypothesis. A pair of two-year-old swans, named Carl and Cathie, arrived in 1955 and overwintered in the Moose Jaw Animal Park. On 3 May 1956 these two pinioned mention of Regina's "two senior swans, Joe and Moe, and their four cygnets" which had been released at Rotary Park, Regina, the day before (photo and caption in Regina Leader-Post 9 May 1956). It may ever remain a mystery whether or not the latter six swans were part of the same shipment from England.

When the Queen and Prince Philip visited the Saskatchewan Museum of Natural History in July 1959, they in turn were hosted by Fred Bard ("Observant: that's how Prince Philip impressed museum men," Regina Leader-Post, 24 July 1959). That visit fulfilled one requirement for the later museum name change proclamation in 1993 to the Royal Saskatchewan Museum (Graham Preston, pers. comm.).

In March 1963 a SMNH pamphlet, "Wascana Marsh," featured 16 bird species of interest, including the

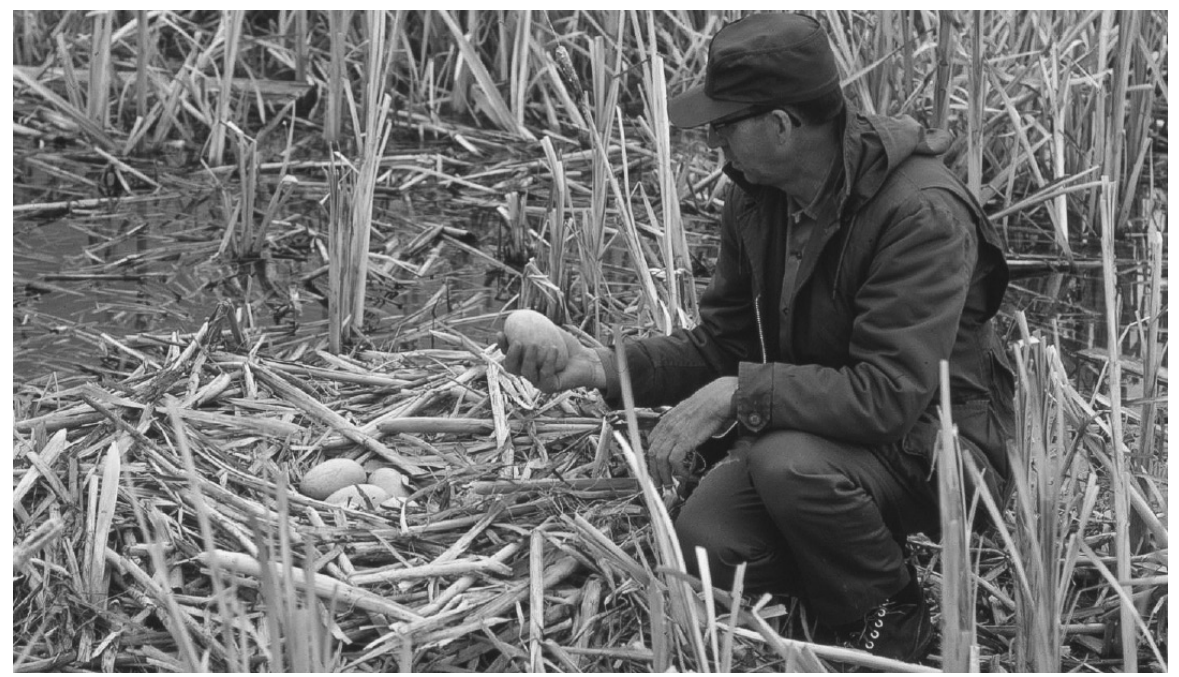

Fred Bard at Mute Swan Nest - Tern Island Wascana Lake

- Fred Lahrman

three-year-old swans were released by W.A.C. Leitch and Walter Sweet of the Regina powerhouse staff, with Fred Bard looking on (Regina Leader-Post, exact date missing). The situation is somewhat confused, however, by
Mute Swan, "an introduced species."6 In November 1964, the Museum pamphlet, "Swans, Ducks, Geese and Cranes of Saskatchewan," contained sketches and text concerning Trumpeter and Whistling [now Tundra] Swans, and 
a photograph of the year-round Mute Swans feeding at Wascana Lake. ${ }^{7}$ But there was no indication of the source of the year-round swans.

Might the swans have come from the small flock known as "the Royal Swans" in Ottawa? Not a chance! The chronology was wrong. Not until 1967, in honour of Canada's Centennial Year, did Ottawa receive six pairs of pinioned Mute Swans, from Her Majesty Queen Elizabeth (CBC News Broadcast, 25 Jun 2010, 9:19 am EST, downloaded 7 Feb 2011). Christine Hartig, Ottawa's Royal Swan Program coordinator, informs me that these swans, pinioned at seven days of age, had been sent from the River Thames near Abingdon-on-Thames, $9 \mathrm{~km}$ south of Oxford, England. "They were a gift from Her Majesty Queen Elizabeth II to commemorate the Centennial of the confederation in 1967. Ottawa, as Capital, was the recipient of this Royal gift on behalf of the Nation." (Christine Hartig, Power Point Swan presentation, February 2011). The Royal Swans in Ottawa had not, as some of us had guessed, originated from Peter Scott's Severn Wildfowl Trust at Slimbridge, Gloucestershire, the home of the world's largest collection of waterfowl. The arrival of swans in Ottawa had occurred 12 years following the arrival of Mute Swans in Regina. Janice Dowling of Ottawa sent me a news item from the Ottawa Citizen "Royal Swans may soon escape Swantanamo Bay" for a needed $\$ 375,000$ shelter (CBC News Broadcast, 25 Jun 2010, 9:19 am EST, downloaded 7 Feb 2011).

However, the thought of ceremonial exchanges within the British Commonwealth brought to mind Ralph Edwards at the appropriately-named Lonesome Lake in the interior of British Columbia. His altruistic efforts to save another species of swan, the Trumpeter, were described by Leland Stowe, a best-selling author, Pulitzer prize winner, and roving editor for Reader's Digest. Chapter 14, "Saga of the Trumpeter Swans," in Crusoe of Lonesome Lake reveals a series of remarkable coincidences. ${ }^{6}$ John P. Holman of Fairfield, Connecticut, happened to come over the mountains in 1925 to Lonesome Lake, B.C., to hunt Grizzly Bears; he met and hired Ralph Edwards as his guide. Holman, an amateur ornithologist and a member of the Audubon Society, was amazed to see the substantial but hitherto unknown wintering population of endangered Trumpeter Swans and reacted "like a prospector hearing of a gold strike." He quickly shared his findings with J.A. Munro of the Canadian Wildlife Service (CWS), and with the world. Edwards shortly became an unpaid bird warden for CWS. ${ }^{6}$

1930 brought an unusually severe winter to Lonesome Lake; only 19 of the swans survived. Realizing the value of this flock, CWS provided grain to Ralph Edwards and his daughter Trudy - half a pound of barley per swan per day. The swans became habituated to the daily feeding time of 11 a.m. and the flock size grew to 130 by about $1950 .{ }^{6}$

How does the Trumpeter Swan fit into the Mute Swan story? When Princess Elizabeth visited Canada in 1951, Peter Scott asked whether, in honour of that Royal Visit, Canada might make a gift of Trumpeter Swans to the Princess and the British people. There was only one place in Canada where Trumpeter Swans were tame enough to capture and Trudy Edwards was the only person who could get close to them. The next year, 1952, Princess Elizabeth became Queen on 6 February. That summer, CWS biologists Ronald H. McKay and Dave Munro flew in from Vancouver to assist Trudy once she had caught the swans. ${ }^{6}$ The five captured Trumpeter Swans were the first ever to be flown across the Atlantic. Trudy Edwards received a personal letter of thanks from Queen Elizabeth and another thank-you from Governor-General Vincent Massey. 
For a few years, as a Patron of the Wildfowl Trust, the Queen, accompanied by her keen conservationist husband Prince Philip, paid almost annual visits to Slimbridge; their third visit was in pouring rain in April 1961 ("Umbrella Day at Slimbridge: Royal Party tour [sic] wildlife pens," Dursley Gazette, 28 April 1961). Slimbridge, the first Wildfowl and Wetlands Trust reserve, opened 10 November 1946. However, a review of the Wildfowl Trust's Annual Reports (WTAR) from the mid 1950s Dr Eileen Rees, Head of UK Waterbird Conservation at WWT, did not find any mention of Slimbridge being the source of the Mute Swans arriving in Saskatchewan in 1955, which therefore must have come from elsewhere. Incidentally, Peter Scott was knighted by the Queen in 1973.

Nevertheless, it may not be too fanciful to suggest that the Canadian gift of Trumpeter Swans to Slimbridge was among the considerations, although not a delayed reciprocity, for the Mute Swans that had come to Regina in 1955 from some other location in England. Lorne Scott and I suspect that Fred Lahrman thought so.
1. BELCHER M (1980) Birds of Regina (revised edition). Saskatchewan Natural History Society Special Publication 12:1-151.

2. LONG JL (1981) Introduced birds of the world. Universe Books, New York.

3. LEVER C (1987) Naturalized birds of the world. Longman Scientific \& Technical, Harlow, Essex, England.

4. GODFREY WE (1966) The Birds of Canada. National Museum of Canada Bulletin 203.

5. BELCHER M (1961) Birds of Regina. Saskatchewan Natural History Society Special Publication 3:1-76.

6. ANONYMOUS (1963) Wascana Bird Sanctuary. Saskatchewan Museum of Natural History Popular Series No. 6.

7. ANONYMOUS (1964) Swans, Geese and Ducks and Cranes of Saskatchewan. Saskatchewan Museum of Natural History Popular Series No. 9.

8. STOWE L (1957) Crusoe of Lonesome Lake. Random House, New York.

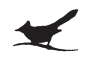

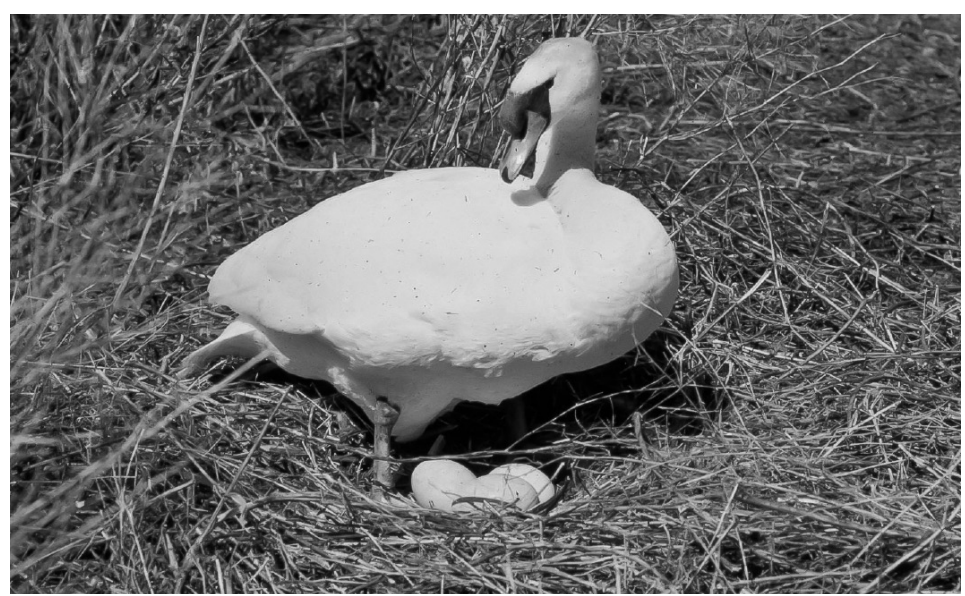

Mute Swan at Nest 